\title{
STUDIES IN SEARCH OF A SUITABLE EXPERIMENTAL INSECT MODEL FOR XENODIAGNOSIS OF HOSTS WITH CHAGAS' DISEASE \\ 4-THE REFLECTION OF PARASITE STOCK IN THE RESPONSIVENESS OF DIFFERENT VECTOR SPECIES TO CHRONIC INFECTION WITH DIFFERENT TRYPANOSOMA CRUZI STOCKS*
}

\author{
Alina Perlowagora-Szumlewicz** \\ Carlos Alberto Muller* \\ Carlos José de Carvalho Moreira*
}

PERLOWAGORA-SZUMLEWICZ, A. et al. Studies in search of a suitable experimental insect model for xenodiagnosis of hosts with Chagas' disease. 4. The reflection of parasite stock in the responsiveness of different vector species to chronic infection with different Trypanosoma cruzi stocks. Rev. Saúde públ., S. Paulo, 24: $165-77,1990$.

\begin{abstract}
Previous studies $(1982,1987)$ have emphasized the superiority of sylvatic vector spedes over domestic species as xenodiagnostic agents in testing hosts with acute or chronic infections by $T$. cruzi " $Y^{\prime \prime}$ stock. The present study, which is unique in that it contains data on both infectivity rates produced by the same stock in 11 different vector species and also the reaction of the same vector species to seven different parasite stocks, establishes the general validity of linking efficiency of xenodiagnosis to the biotope of its agent. For example, infectivity rates produced by "Săo Fellpe" stock varied from 82.5\% to $98.3 \%$ in sylvatic vectors but decreased to $42.5 \%$ to $71.3 \%$ in domestic species. "Colombiana" stock produced in the same sylvatic vectors infectivity rates ranging from $12.5 \%$ to $45 \%$. These shrank to $5 \%$ 22.5\% in domestic bugs. The functional role of the biotope in the vector-parasite interaction has not been elucidated. But since this phenomenon has been observed to be stable and easy to reproduce, it leads us to believe that the results obtained are valid. Data presented also provide increasing evidence that the infectivity rates exhibited by bugs from xenodiagnosis in chronic hosts, are parasite stock specific. For example, infectivity rates produced by "Berenice", " $\mathrm{Y}^{\prime \prime}$, "FL" and "CL" varied in $R$. reglectus from $26.3 \%$ to $75 \%$; in $P$. megistus from $56.3 \%$ to $83.8 \%$; in $T$. sordida from $28.8 \%$ to $58.8 \%$ in $T$. pseudomaculata from $41.3 \%$ to $66.3 \%$ and in T. rubrooaria from $48.8 \%$ to $85 \%$. Data from xenodiagnosis in the same hosts, carrying acute infections by the same parasite stocks, gave the five sylvatic vectors a positive rating of approximately $100 \%$, thus suggesting that the heavy loads of parasites circulating in the acute hosts obscured the characteristic interspecific differences for the parasite stock. Nonetheless these latter were revealed in the same hosts with chronic infections stimulated by very low numbers of the same parasite stocks. Certain observations here described lead us to speculate as to the possibility of further results from other parasite stocks, allowing the association of the infectivity rates produced in bugs by different parasite stocks with the isoenzymic patterns revealed by these stocks.
\end{abstract}

KEYWORDS: Trypanosomiasis, South American, diagnosis. Insect vectors, parasitology. Hostparasite relations. Triatoma, parasitology. Panstrongylus, parasitology. Rhodnius, parasitology. Trypanosoma cruzi, patogenicity.

\section{INTRODUCTION}

Insect models of vector parasite association in Chagas' disease are meant to determine the patterns of parasite population dynamics exhibited by the same parasite stocks utilizing different vector species, and/or by the same vector species infected with different parasite stocks. The most important criterion for identifying a successful insect model is its ability to maintain a high proportion of its population infected upon feeding on chagasic hosts.
The Trypanosoma cruzi " $Y$ " stock used in previous studies 2,24 , as a prototype for identification of an cfficient xenodiagnostic agent from among nine vector species represented by six sylvatic insects which have been found with increasing frequency in human houses over the last two decades, were: Rhodnius neglectus, Panstrongylus megistus, Triatoma brasiliensis, Triatoma sordida, Triatoma pseudomaculata and Triatoma rubrovaria. The other three were: the domectic Triatoma infestans, Triatoma dimidiata and Rhodnius prolixus. This latter has been found by Gamboa ${ }^{1 /}$ and Go-

- Presented in part at the Annual Meeting on Basic Research in Chagas' Disease. Caxambu, MG, Brazil, 1988.

* Laboratory of Vectors of Chagas' Disease. Dept. of Entomology. Oswaldo Cruz Institute Foundation (FIO CRUZ) - Estr. da Covanca, 56 - Jacarepaguá - 22700 - Rio de Janeiro, RJ - Brazil. 
mez-Nunez ${ }^{16}$, through precipitin tests and marking recapture studies for bug dispersion, to interchange between natural and artificial habitats.

The distinctive differences in the bugs' responsiveness to infection, illustrated by the nine vector species, and the remarkable homogeneity of the good reactions within the group of sylvatic bugs, have permitted the identification of two distinct vector groups. The group of sylvatic bugs seem to reinvigorate the infectivity potential of the parasite, thus providing efficient candidates for xenodiagnosis. As for the second group, composed of the domestic $T$. infestans, $T$. dimidiata and $R$. prolixus, mobile between human houses, peridomestic areas and woodland, the infectivity rates produced by the same parasite were rather low, indicating their inadequacy for xenodiagnosis. Nonetheless the domestic bugs continue to be of major importance in the trasnsmission of the disease.

Although research on the vector parasite relationship, as illustrated by data from xenodiagnosis, has been under way in our laboratory for several years, it is still necessary to emphasize the consistency of the observation regarding the superiority of sylvatic vectors for xenodiagnostic purposes as stressed in the two recent papers 24,25 . The fact that this phenomenon is remarkably stable and easy to reproduce leads to the belief that the differences recorded between the groups of sylvatic and domestic vectors are valid, even though the nature of the reaction with regard to the biotope of the vector is not yet understood.

As yet, there is no evidence to support any other grouping of vector responsiveness to infection by $T$. cruzi, as based on data from xenodiagnosis, hence these authors continue to oppose the concept stressed by some other investigators as capable of explaining increased vector infectivity as due to the exploitation of a mutual adaptation thought to operate between vectors and parasites derived from the same geographical area. Instead, greater emphasis is here given to the use of completely wild or essentially sylvatic bugs in the process of invading human homes. These insects found in human dwellings over the last 2-3 decades have not so far settled there for good (Forattini et al. 11, 12) and will probably continue to have the characteristics of sylvatic insects for many years to come, depending mostly on the intensity of the industrialization occurring in the endemic regions under control. This is also the reason for the use of the term "essentially sylvatic" when analyzing the responsiveness of these vector species to infections by T. cruzi stocks.

The divergencies between the present authors and other workers have been generated chiefly by differences of opinion 1 in the analysis of similar sets of data. Consequently, the varying interpretations have lead to divergent opinions. Thus, comments concerning the diversity of bug respon- siveness to infection by $T$. cruzi is a matter of interpretability rather than of substance, because apparently all record the poor performance of the parasite in the domestic $T$. infestans, as compared with that found by Ryckman ${ }^{27}$; Little et al. ${ }^{17}$ in the wild $T$. protracta, or in the wild $D$. maximus, as stated by Barreto et al. 5 , and also in the six essentially sylvatic species utilized by us in previous studies $23,24,25$.

Additional data, from xenodiagnosis in hosts infected with different parasite stocks, have established the generality of diverse infectivity rates among sylvatic and domestic bugs exposed to acute infections by seven parasite stocks: "Berenice", "Y", "FL", "CL", "São Felipe", "Colombiana" and "Gávea", as reported by Perlowagora-Szumlewicz et al. ${ }^{25}$ (1988).

However the practical significance of this finding still awaits confirmation through the establishment of the fact that it is also applicable to chronic infection by the same $T$. cruzi stocks.

The present paper is therefore entirely devoted to experimental chronic Chagas' disease in guinea-pigs, used in xenodiagnosis with 11 vector species at intervals varying from 429 to 807 days after infection with the seven $T$. cruzi stocks.

\section{MATERIAL AND METHOD}

Triatominae: Of 11 vector species used, nine were essentially those utilized by us previously (1982, 1987, 1988). While research on upgrading xenodiagnosis has been under way for several years, two vector species, as yet untested, were included on the supposition that there might be other bugs which were superior as xenodiagnostic agents. In fact, of the several hundreds of vector species distinguished in Brazil, less than a dozen have been screened for xenodiagnostic purposes.

The origin and life history of the nine laboratory-reared vector species were given by Perlowagora-Szumlewicz and Muller ${ }^{23}$ (1982). The two additional species were Triatoma vitticeps, derived from Macać, Rio de Janeiro, and Triatoma pessoai collected in Bahia (Brazil).

On the basis of surveys centered on household infestation, described by Barreto and others, these bugs could be divided into three groups at the start of their colonization in our laboratory: one composed of the highly domiciliated Triatoma infestans practically no longer found in the wild. Triatoma dimidiata and Rhodnius prolixus, traced to exchange between natural and artificial biotopes by Gamboa ${ }^{14}$ (1963) and Gomez-Nunez ${ }^{16}$ (1969).

The second group consisted of the following Triatoma: sordida, pseudomaculata, brasiliensis, vitticeps, pessoai and Panstrongylus megistus. All are essentially sylvatic but some, like $T$. sordida 
and $P$. megistus, have been found colonizing human homes under control, following successful application of insecticides against $T$. infestans, as described by Rocha e Silva et al. ${ }^{26}$, Barreto ${ }^{4}$ and Forattini et al. $9,11,12$.

Of the last two species, $R$. neglectus and $T$. rubrovaria, the former, considered completely wild when brought to the laboratory, was found in artificial habitats, in regions of intensive agricultural and cattle breeding activities, by Forattini et al. ${ }^{10}$ (1979). The latter was found in human homes by Silveira et al. ${ }^{28}$ (1984).

Mammalian hosts: The authors made use of laboratory infected guinea-pigs used in a previous study on the interaction of vector species and parasite stock in the responsiveness of bugs to acute infections with the following $T$. cruzi stocks: "Berenice", "Y", "FL", "CL", "São Felipe", "Colombiana" and "Gávea". The origin of these has been described in a recent paper ${ }^{25}$.

Rather than repeat the mode of infection of the animal hosts with the seven parasite stocks and the process of using the former in feeding several thousand noninfected bugs of different species, utilized thereafter in xenodiagnosis of acute Chagas' disease, the reader is referred to the paper ${ }^{25}$ published in 1988 , in which the xenodiagnostic test applied to the hosts, which survived the acute infection and remained in the chronic phase of the disease is described.

Xenodiagnosis: Of the 42 guinea-pigs used in the previous study ${ }^{25}$, only 33 recovered from the acute infection that lasted from 57 to 67 days after inoculation of "Berenice", " $Y$ ", "FL" "CL" and "Colombiana", and from 145 to 190 days after infection with "São Felipe" and "Gávea" stock.

The 33 animals shown by examination of ear blood to be free of parasites, for periods varying from 429 to 510 days after inoculation, were used in the first xenodiagnosis. The second test was performed in 27 animals only, at intervals varying from 731 to 807 days after infection, because six of the chronic animals died between the tests. The lack of apparent chronic chagasic syndromes in the dying animals suggest that the deaths could be related to the aging of the hosts.

Fourth instar nymphs of each of the 11 vector species, starved during a period of 2-3 weeks after transition from the third stage, were fed on the chronic guinea-pigs in accordance with scheme described by us in $1988^{25}$.

The tutal number of bugs of the 11 species exposed to infection by seven parasite stocks was 6,332 , of which only 5,756 were utilized in the two xenodiagnostic tests. The excess of bugs fed was set aside for emergency replacement in cases of natural deaths, involuntary mistreatment, or rejcction because of inadequate engorgement.
Groups of 484 specimens of each species were fed in batches, the number of which was equivalent to that of the available hosts tested (Table 1, column 2). Accordingly bugs were fed in three batches of 161 specimens each, on three available animals; in four batches of 121 specimens each, on four living guinea-pigs, in five batches of 97 each, on five infected guinea-pigs and in six batches of 81 each, on the original number of six animals used in the previous study ${ }^{25}$. None of this group died.

Bugs usually became engorged within 25-30 min. The well fed specimens were pooled by species infected with the same parasite stock in glass cylinders $(16 \times 22 \mathrm{~cm})$ covered with cheese cloth, thus forming two sets of 76 cylinders, one housing bugs from the first and the other from the second xenodiagnosis.

Bugs were examined for infectivity rates and parasite population density at $30,45,60,90$ and 120 days after infection. During this period bugs were fed on chicken blood at biweekly intervals. Examination of bugs for infectivity rates and for the proportion of those with heavy infections was as described by Perlowagora-Szumlewicz and Muller ${ }^{23}$ (1982).

\section{RESULTS}

Biological insights into vector parasite interaction, as shown by data from the xenodiagnosis suminarized in Tables 1 and 2 look somewhat messy. The pattern of fluctuating infectivity rates and the alternate ups and downs of parasite densities in bugs fed on the same animal host seem to be a constant phenomenon, embarrassing to the investigator in his attempts to interpret the results obtained.

With the objective of making the task of the investigator easier and keeping down the printing costs of innumerable data from long term experiments, two recommendations have been adopted, both operational in nature and of immediate ap. plication, stressed by the authors in a previous paper 24: 1- that for a complicated system such as the vector parasite relationship in Chagas disease, the best way to analyze data collected is through overalls; and 2- that the reaction of bugs to chronic infection is unrelated to the time elapsed between the termination of the acute phase of the infection in the animal host and its transmission to the invertebrate host used in xenodiagnosis, thus allowing the pooling of results from various consecutive tests at increasing intervals of time following infection.

While the pooling of data results in some loss of information, it makes possible a satisfactory analysis of prevalence and intensity of infections exhibited by different vector populations engorged from infected hosts. Nonetheless, in order to avoid the loss of otherwise important information, be- 
yond that needed for xenodiagnosis, all data used in the computing of overalls are shown in Tables 1 , 2 . These data provide also an efficient safeguard against any biased or mistaken interpretation of results, because the causes of such would be easily discovered amid the unmanipulated numbers recorded in the laboratory protocols on the examination of the bugs.

The first two sections of results deal with the present data derived from xenodiagnosis in chronic animals. The third section compares present and previous data taken from xenodiagnosis in the same animals in the acute phase of infection. This makes it possible to focus on the overall aspect of the parasite infectivity potential represented by two biological parameters, the product of a dynamic process moving from the acute to the chronic phase of the disease in the same host.

Infectivity Rates in Bugs of Different Species Engorged From Hosts With Chronic Infections by Different $T$. cruzi Stocks. The responsiveness to the infectivity potential of the seven different $T$. cruzi stocks by all the different vector species is shown by the horizontal lines of Table 1 . The responsiveness found in the same vector species engorged from hosts infected with different $T$. cruzi stocks is seen in the vertical columns of the same Table.

Past studies 23,24 have emphasized the superiority of sylvatic bugs over domestic ones as xenodiagnostic agents for recognition of the infection by $T$. cruzi $Y$ stock. Consequently, as has been recommended since 1982, domestic bugs should not be resorted to for xenodiagnostic purposes. The reason for including them again in this study was, to some extent, to reinforce the consistency of the apparently paradoxical concept of linking the diversity of infectivity rates, exhibited by the vector species, to their biotopes. The main reason, however, was to answer the obvious question that arose. Is there a similar correlation between infectivity rates in bugs engorged from hosts with chronic infections by other $T$. cruzi stocks? The question is answered by the quantitative data summarized in Table 1.

The highest infectivity rates found in eight sylvatic vector species, engorged from hosts with chronic infection by "São Felipe" stock, varied from $82.5 \%$ to $98.3 \%$ while it ranged from $42.5 \%$ to $71.3 \%$ in the three domestic species. The lowest infectivity rates were found in sylvatic bugs engorged from hosts with chronic infections by "Colombiana" stock, varying from $12.5 \%$ to $45 \%$. A nearly twofold decrease in these latter was found in the domestic species, the proportion of positive bugs ranging from $5 \%$ to $22.5 \%$. Between these extremes, intermediate levels of infectivity rates in bugs were produced by the remaining five $T$. cruzi stocks. Results obtained in all of these cases also led to the association of vector responsiveness to infection with their habitat.
These results are the first clear demonstration that the phenomenon of sylvatic vectors as xenodiagnostic agents is not restricted to " $Y$ " stock, used in previous studies, 23,24 but is also valid for the detection of chronic infections produced by any of the $T$. cruzi stocks here screened, regardless of whether the infectivity potential of the parasite stock is high, as in "São Felipe", low as in "Colombiana" or intermediate as in the remaining stocks.

That the parasite stock is involved in the magnitude of infectivity rates established in vector species is clearly shown by data given in Table 1. For example, the infectivity rates in $P$. megistus, engorged from guinea-pigs with chronic infection by "Berenice", "São Felipe" and "Gávea", were $83.8 \%, 96.3 \%$ and $87.5 \%$ respectively, while it was only $25 \%$ upon feeding on guinea-pigs with chronic infection by "Colombiana". T. rubrovaria, under identical conditions, displayed infectivity rates of $85 \%, 98.3 \%$ and $86.6 \%$ respectively, while this has been as low as $27.8 \%$ upon feeding on hosts with chronic infections by "Colombiana". Both of these vector species engorged from hosts with chronic infections by "CL", "FL" and " $Y$ " exhibited intermediate infectivity rates, varying in P. megistus from $56.3 \%$ to $71.3 \%$ and in T. rubrovaria from $48.8 \%$ to $73.8 \%$.

Parasite Density in Bugs of Different Species Engorged from Hosts with Chronic Infections by Different T.cruzi Stocks. In general the most useful indices of parasite density are the number of parasites per microscopic field and the magnitude of the vector population with such numbers. Accordingly, the overalls shown in Table 2 are based on the proportion of positive bugs with parasite counts equal or superior to 11 parasites in 50 fields.

This parameter follows the pattern outlined for the infectivity rates observed in domestic and sylvatic bugs of different vector species shown in Table 1. The overall percentage of bugs displaying large parasite populations is superior in sylvatic to that in domestic vector species, regardless of the fact that both were engorged from the same hosts. For example, whereas the percentage of the domestic $T$. infestans with heavy infections ranged from 0 to $46.4 \%$, it varied from $50 \%$ to $77.6 \%$ in the essentially wild $T$. rubrovaria. Similarly the proportion of bugs with heavy infections varied from $52.4 \%$ to $84.2 \%$ in the essentially sylvatic $R$. neglectus, while it was lower in the domestic $R$. prolixus, ranging from $4.3 \%$ to $61.1 \%$.

The rate of positive bugs with heavy infections, as seen in Table 2, may or may not parallel the prevalence rates shown in Table 1 . The parallel action of these two parameters is well exemplified by $T$. sordida, in which the peaks of both, $91 \%$ approximately, were produced by "São Felipe" stock. The lack of parallelism between the two parameters is seen in $T$. rubrovaria. The peak 


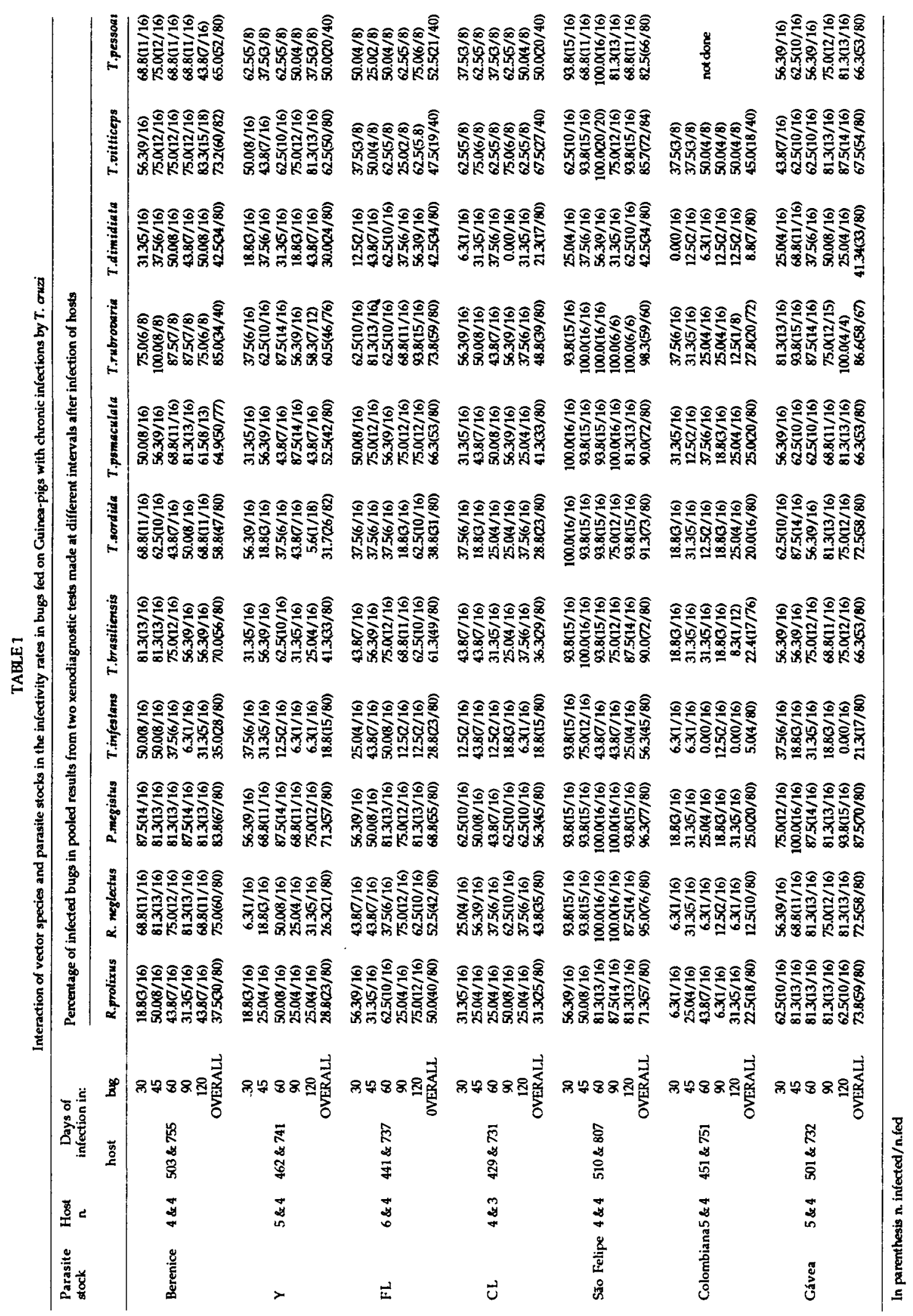




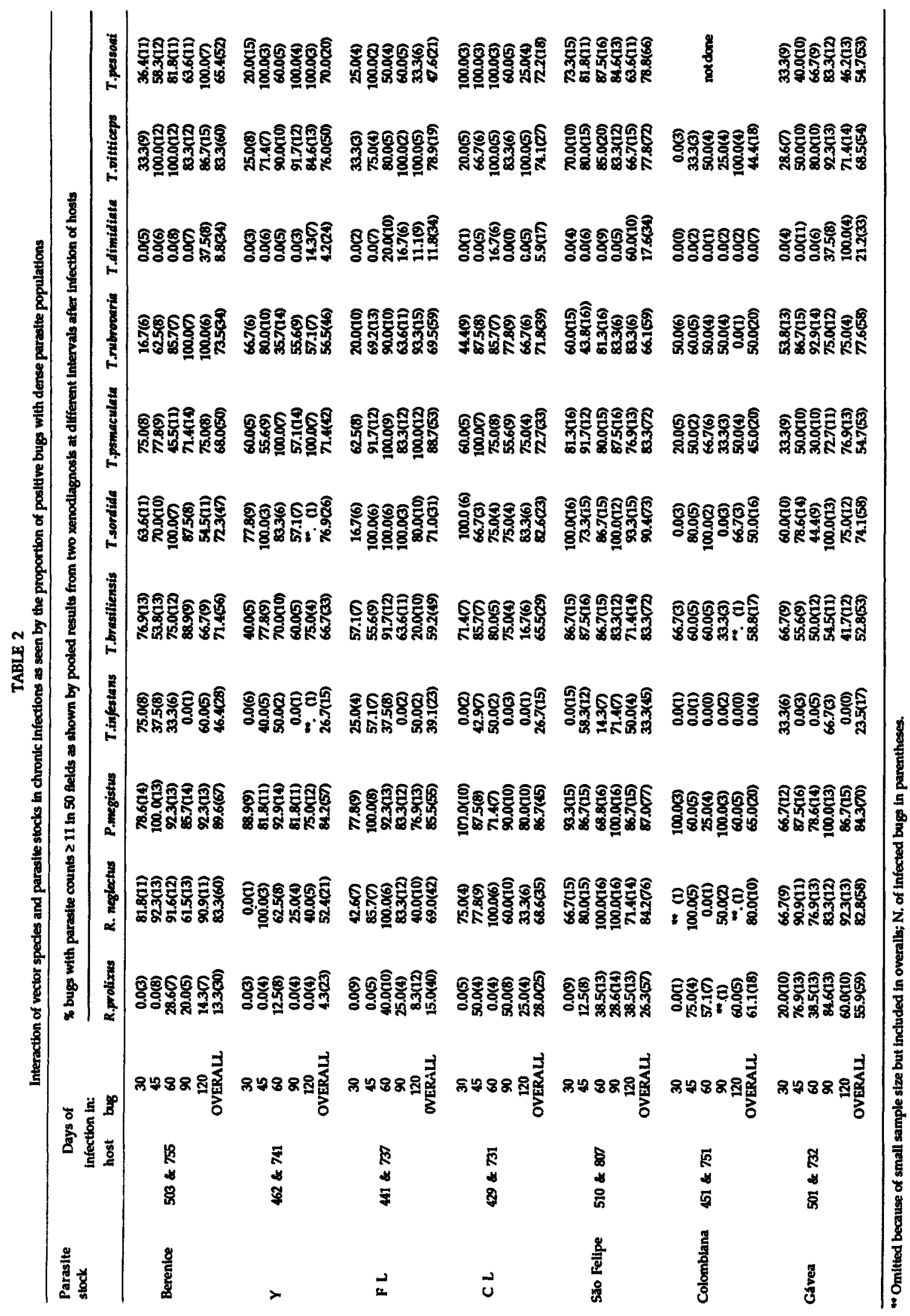




\begin{tabular}{|c|c|c|c|c|c|c|c|c|c|c|c|}
\hline & R.pr & R.ne & P.me & T.in & $T . b r$ & T.so & T.ps & T.ru & T.oi & T.pe & T.d \\
\hline Berenice & $x x$ & 0 & 0 & $x x$ & 00 & 0 & 0 & 0 & 0 & 0 & $x x$ \\
\hline$Y$ & $x x$ & $\times 0$ & 0 & $x x$ & $\times 0$ & $\times 0$ & $\times 0$ & 0 & 0 & $\times 0$ & $x x$ \\
\hline FL & $x x$ & $\times 0$ & 0 & $x x$ & 10 & $\times 0$ & 0 & 0 & $\times 0$ & $x x$ & $x x$ \\
\hline$C L$ & $x x$ & $\times 0$ & $\times 0$ & $x x$ & $\times 0$ & $\times 0$ & $\times 0$ & xo & 0 & $\times 0$ & $x x$ \\
\hline São Felipe & $\theta x$ & 0 & 0 & $x x$ & 00 & $\bullet$ & 0 & 0 & 0 & 0 & $x x$ \\
\hline Colombiana & $\times 0$ & $\times 0$ & $\times 0$ & $x x$ & $\times 0$ & xo & $x x$ & $\times 0$ & $x x$ & -. & $x x$ \\
\hline Gávea & 0 & 0 & 0 & $x x$ & 0 & 0 & 0 & 0 & 00 & 00 & $x x$ \\
\hline
\end{tabular}

Fig. 1 - Graphical representation of vector species which represent at least $60 \%$ of positives $\bullet$, of which $50 \%$ carry parasites counts $\geq 11$ in 50 fields $O$ upon feeding on hosts with chronic infections by different $T$. cruzi stocks; $x$ stands for vector species with lower rates than those estimated for a successful xenodiagnosis (for real values see "overalls" in Table 1,2$) ;+$ infectivity rate slightly lower $(58.8 \%)$ than the estimated minimum; - not done. Abbreviations haeding this Fig. and others stand for: prolixus, neglectus, megistus, infestans, brasiliensis, sordida, pseudomaculata; rubrooaria, vitticeps, pessoai, dimidiata.

of $77.6 \%$ of specimens with dense parasite populations was produced by "Gávea" stock, while the peak of $98.3 \%$ of infectivity rates was stimulated by "São Felipe" stock. Cases like this latter, if found with frequency, would create difficulties in the choice of adequate xenodiagnostic agents. However, the experience of the recent authors in performing xenodiagnosis in animal hosts with experimental infections allows an estimation of a minimum rate of $60 \%$ of infected bugs, of which at least $50 \%$ carry heavy infections, permitting a productive xenodiagnosis.

This assumption helped to piece together a more favourable portrait of the efficiency of the vector species for xenodiagnosis in hosts carrying chronic infections by different T.cruzi stocks, as shown by the scattergram of Fig. 1 and by the smoothly arranged data in Fig. 3, from which those derived from domestic bugs have been omitted.

The joint action of both parameters, as displayed in Fig. 1 (horizontal lines) by the infectivity rates $\geq 60 \%(\bullet)$ and dense parasite populations $\geq 50 \%$ (0), was observed in all eight sylvatic vectors exposed to chronic infection by "Berenice", "São Felipe" and "Gávea". Four of these vectors reacted well to infection by "FL". Three responded well to infection by " $Y$ " stock, only one reacted well to infection by " $\mathrm{CL}$ " and none responded adequately to infection by "Colombiana".

The vertical columns in this Figure show that $P$. megistus, $T$. rubrovaria and $T$. vitticeps responded well to infections induced by any of five different parasite stocks. Chronic infections produced by four of the parasite stocks elicited a response from $T$. brasiliensis and $T$. pseudomaculata. Three of the parasite stocks produced high infectivity rates in R.neglectus, T.sordida and T.pessoai. It is noteworthy that, under identical conditions, none of the chronic infections produced by the seven different parasite stock elicited an adequate response from the domestic T.infestans or T. dimidiata; R. prolixus, well known to exchange between human homes and palm trees, responded to chronic infection by "Gávea" stock only.

Comparison of Vector Responsiveness to Acute and Chronic Infections in the Same Hosts Infected with the Same Parasite Stocks. The opportunity to make this kind of comparison was at hand because results here reported represent a follow-up of those from the recent study ${ }^{25}$ on the reaction of different vector species to acute infections by the different parasite stocks.

Figure 2 summarizes the data from xenodiagncsis in guinea-pigs with acute infections by seven different $T$. cruzi stocks extracted from our recent paper ${ }^{25}$. What is lacking in this Figure is the reaction of $T$. vitticeps and $T$. pessoai to the acute infections by different T.cruzi stocks. These two species were late comers in the group of tested vector specics and wore not available in the numbers used at the start of the experiments on the xenodiagnosis in hosts with the acute infections.

In order to make data comparable, the graphical representation of the behavior of both parameters in Fig. 2 was also based on the estimated minimum rate of $60 \%$ of infected bugs, of which at least $50 \%$ carry dense parasite populations. Data in Tables 1, 2, described previously, ${ }^{25}$ give the sylvatic bugs engorged from hosts with acute infections a positive rating above $90 \%$, of which at least $75 \%$ or more harbored parasite counts $\geq 11$ in 50 fields. 


\begin{tabular}{|c|c|c|c|c|c|c|c|c|c|c|}
\hline & $R . p r$ & R.ne & P.me & T.in & $T . b r$ & T.so & T.ps & T.ru & T.vi & T.pe \\
\hline Berenice & $x$ & 0 & 00 & 0 & 10 & 0 & 0 & 00 & $\cdots$ & - \\
\hline$Y$ & - $x$ & 0 & 00 & $\times 0$ & 0 & 00 & 00 & 0 & - & $\cdots$ \\
\hline $\mathrm{FL}$ & 00 & 0 & 00 & 0 & $x$ & 0 & 0 & 00 & $\cdots$ & $\cdots$ \\
\hline $\mathrm{CL}$ & - $x$ & 0 & - 0 & $\times 0$ & 00 & 90 & 00 & 0 & $\cdots$ & $\cdots$ \\
\hline São Felipe & - $x$ & 0 & 0 & $\times 0$ & 0 & 00 & 0 & 10 & $\cdots$ & $\cdots$ \\
\hline Colombiana & 0 & 0 & 0 & 0 & 0 & 20 & 0 & 0 & $\cdots$ & $\cdots$ \\
\hline Gávea & 0 & 0 & 10 & $e_{x}$ & 10 & 00 & 0 & 10 & $\ldots$ & $\ldots$ \\
\hline
\end{tabular}

Fig. 2 - Graphical representation of vector species in which acute infections with different $T$. cruzi stocks produce at least $60 \%$ of infectivity rates $\bullet$, of which $50 \%$ carry parasites counts $\geq 11$ in 50 fields 0 ; $x$ stands for lower values than those shown in the graph (for real values see data described previously, 25); - not done.

The relatively low frequency in infectivity rates above $60 \%$ observed in some vector species shown in Fig. 1, as compared with those registered in those species engorged from the acute hosts seen in Fig. 2, is not surprising because the former were found in bugs engorged from hosts, which survived the acute irfections, thus indicating that the immune and other protective mechanisms had time enough to dramatically reduce the number of parasites in the hosts, but did not eliminate them completely, as demonstrated by the results from the xenodiagnosis here described and discussed.

This, however, does not explain the fascinating uniformity observed among infectivity rates in bugs engorged from hosts with acute infections by different parasite stocks ${ }^{25}$, as compared with the diverse infectivity rates found in the same vector species exposed to chronic infections by the same parasite stocks, as shown by the overalls inTable 1. This might suggest that the reflection of the parasite - stock involvement in the vector parasite interaction becomes apparent in the invertebrate hosts engorged from hosts with weak, or disguised infections. The discussion of this paper will return to this concept and the respective comments.

\section{DISCUSSION}

The present paper has compared sets of data from xenodiagnosis with 11 vector species in guinea-pigs, which survived the experimental acute infections induced by seven different T.cruzi stocks: "Berenice", "Y", "FL", "CL", "Sæao Felipe", "Colombiana" and "Gávea".

The " $Y$ " stock has been used in two previous studies 23,24 as a prototype for the identification of an efficient xenodiagnostic agent in a group of nine different vector species.

The good adaptation of this parasite stock to sylvatic bugs, shown by the high infectivity rates and the great proportion of positives with dense parasite populations, motivated the grouping of the vectors into sylvatic and domestic species, which might be responsible for the diversity of results from xenodiagnosis reported by different investigators.

Every report written on the long-term study, in search of an experimental vector model for xenodiagnosis, reinforced what had been recognized right at the beginning of the experiments in 1982, as to the superiority of the sylvatic vectors as xenodiagnostic agents.

One obvious question arose. Is there a similar correlation between the sylvatic vector and its responsiveness to chronic infections by other parasite stocks, or is it restricted only to the "Y" stock tested? The question is answered by the detailed quantitative data and their respective overalls summarized in Tables 1 and 2.

Representative examples of this phenomenon are found among the overalls shown in Table 1. The highest infectivity rates observed in all sylvatic vector species, engorged from guinea-pigs with chronic infections by "São Felipe" stock, varied from $82.5 \%$ to $98.3 \%$ and from $42.5 \%$ to $71.3 \%$ in the three domestic species. The lowest infectivity levels, varying from $12.5 \%$ to $45 \%$, were found in sylvatic bugs engorged from animals with chronic infections by "Colombiana" stock. These shrank to the range of from $5 \%$ to $22.5 \%$ in domestic vector species.

The functional role of the vector biotope in the vector-parasite interaction has not been elucidated. We may, at most, speculate that the poor performance of the parasite stocks tested in the domestic vector species derives from their long 
association with sylvatic animals and sylvatic vectors. Since this phenomenon has been found to be stable and easy to reproduce it leads to the belief that the results are valid, even though not yet understood.

These results are the first clear demonstration of linking prevalence and intensity of infection produced by different parasite stocks in the vector to its biotope. As yet there is no evidence to support any other grouping of vectors that might be responsible for the diverse results recorded between those found in domestic and in sylvatic bugs from xenodiagnosis.

It seems reasonable to ask what the practical implication of the results obtained is. The answer does not differ from that given by the authors in 1982: to use sylvatic rather than domestic vectors as xenodiagnostic agents.

It may be worthy of note that results generated by comparative data (unpublished) from preliminary field xenodiagnosis made in the same patients simultaneously with 20 specimens of T.infestans and the same number of T.vitticeps or P.megistus, demonstrated that the two latter species had already crossed the line of laboratory experiments (termed "theory" by some).

Evidence that the efficiency of xenodiagnosis could be upgraded by the use of the appropriate sylvatic vectors as xenodiagnostic agents has been increasing. Consequently, a shift from the use of $T$.infestans to that of $P$.megistus or T.vitticeps as xenodiagnostic agents, in areas where Chagas' disease is endemic, seems justified at least until more efficient experimental insect models become available."

However, one obvious criticism of the data from comparative tests, using domestic and sylvatic vectors as xenodiagnostic agents, concerns the lack of comparative data from xenodiagnosis, using the same vector species derived from domestic and artificial biotopes. Unfortunately, attemps to find T.infestans, for example, in natural biotopes in areas untreated by insecticides has been unsuccessful.

What really distinguishes this study from those published in 1982 and 1987 is that a great deal of emphasis has previously been placed upon the choice of an experimental insect model for xenodiagnostic purposes, often using " $Y$ " stock only. This report represents the first comparative study giving emphasis to infectivity rates and parasite population density in vectors of different sylvatic species fed on hosts with chronic infections by dif-

\footnotetext{
- Presented at the XXV Congress of the Society of Tropical Medicine and Hygiene, Florianópolis, Brazil, 1989. (Unpublished)
}

ferent parasite stocks.

This is not to say that our views or first principals have changed. They have, rather, been deepened and expanded due to an enhanced interest in the involvement of the parasite in the bugs' responsiveness to infection by T.cruzi. Of major importance was the answer to the question as to whether there existed parasite stock specificity in the vector-parasite relationship that would be revealed in bugs by xenodiagnosis.

Results, as seen from the data in Table 1, brought out increasing evidence of reactions, exhibited by bugs from xenodiagnosis in hosts with chronic infections, which are parasite-stock specific. The differences in vector responsiveness was particularly obvious in the production of rates of positive bugs. For example, the infectivity rate stimulated in P.megistus by "Berenice" stock was $\mathbf{8 3 . 8 \%}$. That produced by "Colombiana" was $25 \%$. Similarly the infectivity rate produced in R.neglectus by "São Felipe" was $95 \%$, while that stimulated by " $Y$ " was $26.3 \%$. This will surely reinforce the feeling that xenodiagnosis as a method for distinguishing chronic infections caused by different $T$.cruzi stocks is inadequate.

However, so as not to overdramatize the situation, attention must be called to the observation, described in Results, that any vector species that exhibits a minimum of $60 \%$ of positive bugs, $50 \%$ of which carry dense parasite populations after feeding on chronic hosts, represents an adequate xenodiagnostic agent, which will lead to a productive test.

The simultaneous action of both of these parameters, as shown in Fig. 1, indicates that all eight of the sylvatic vector species under consideration responded well to chronic infection by "Berenice", "São Felipe" and "Gávea". Four of these vector species responded well to infection by "FL"; three, to infection by "Y". Only one vector species responded adequately to "CL" and none reacted to infection by "Colombiana" stock.

Coincidentelly, two of the three T.cruzi stocks, which contributed most efficiently to the vector parasite interaction, "São Felipe" and "Gávea" have been isolated from P.megistus, the former by Miles et al. ${ }^{18,19}$, Andrade ${ }^{2}$ and Andrade et al. ${ }^{3}$ in "São Felipe", Bahia. The latter was isolated by Perlowagora-Szumlewicz (1979), in "Gávea", Rio de Janeiro (unpublished). The infectivity rates produced by chronic infections with these two strains were comparable to those produced, under the same experimental conditions, by "Berenice", a human isolate. This seems to be in line with the statement of Garcia et al. ${ }^{15}$, that the passage of a homogenous strain of T.cruzi through invertebrate hosts is unable to modify the biological, biochemical and genetic characteristics of the strain. Al- 
though is has not been said, it is to be presumed that it works also in the other direction: invertebrate host mammal.

Interestingly enough, none of the differences seen in the responsiveness of bugs to chronic infections with T.cruzi stocks, have been observed in bugs engorged from the animals with acute infections by the same parasite stocks. Overalls of data described previously ${ }^{25}$ give all sylvatic bugs a positive rating approaching $100 \%$, of which around $75 \%$ or more carried parasite counts $\geq 11$ in 50 fields. Why T.brasiliensis acts differently, exhibiting sometimes higher values of parasite population density in chronic infections (Table 2, overalls), as compared with those in acute infections, is unclear, though is has been observed also in previous reports.

One obvious criticism of the data from acute infections concerns' the inoculum given to the experimental host. Are the extremely high and uniform infectivity rates a reflection of a heavy inoculum? The probability of interspecific differences being undetectable, due to a severe infection produced by the intake of heavy parasite loads, exists. In order to answer this question it was necessary to repeat the study. It is, however, doubtful whether the chronic infection under consideration here will mirror any influence of a heavy infection administered to the hosts 429 or 807 days previously. But as the chronic infection did reveal parasite stock specificity, probably; due to the mild infection produced by the small numbers of parasites that survived, there exists the possibility that interspecific differences between parasite stocks had been obscured by the severe infection produced by the heavy load of parasites present in the acute host.

Results shown in Fig. 1 also deviate substantially from those seen in Fig. 2, although the latter have been based on the assumed minimum value of $60 \%$ infectivity rates, in order to match those summarized in Fig. 1. The real values of infectivity rates were substantially higher, as stated by us previously 25 .

This is not surprising, because the infectivity rates seen in Fig. 1, derived from bugs engorged from hosts, which survived the acute infections, indicate that the immune mechanisms and other protective mechanisms were successful in reducing the number of parasites in the hosts. These latter survived, as did some of the parasites, which escaped the lethal action of the adverse mechanisms and succeeded, sometimes, in making themselves undetectable even by xenodiagnosis.

Another interpretation is that in the chronic phase of the infection, for each sample of insects used in xenodiagnosis, there is only a limited number of parasites available in the peripheral circu- lation which infects some specimens but leaves others free of infection, thus reducing the proportion of positives in the bug from xenodiagnosis. This is unlikely in bacterial diseases but in parasitic infections, in which limited numbers of parasites enter the host, it seems possible.

What is intriguing in the reaction of bugs to chronic infection by different parasite stocks is the behavior of the parasite population density. This, in contrast to the infectivity rates $(\bullet)$, usually reduced in certain vector species, which remained in the assumed proportion of $50 \%$ of positives in all vectores, with the exception of domestic ones, as shown by the open circlets (o), which practically take up the horizontal lines as well as the vertical columns in Fig. 1.

Both the parameters, infectivity rates and parasite population density, exhibited by the vectors from xenodiagnosis, are the product of two mechanisms involved, both strictly associated with the parasite stock. One is its own intrinsic characters of development and growth, the other is its ability to utilize the resources found in the vector.

The species of the vector is probably not the element that will support growth of the parasite but it appears to be as important as the parasite itself, because it provides the necessary elements for the parasite's growth. However, there is no way of getting direct information on this.

Comparing the experimental overalls seen in Table 2 with the assumed values given in Fig. 1, the conclusion is that growth of parasites, called here parasite population density, might undergo alterations in terms of absolute numbers upon the passage from the acute to the chronic phase of the infection but will maintain the rate at which it occurs in the positive bugs constant.

Although the parasite population density gives an accurate portrayal of parasite growth, a parameter otherwise of major importance, it has not proved particularly useful for xenodiagnosis. This test calls for identification of an insect model able to maintain high proportions of its population infected, regardless of the number of parasites producing the infection, be it one or many.

Previous studies ${ }^{23}$ implied the integration of parasite density only in screening vectors for xenodiagnosis, not for use as a determining parameter. It is meant, rather, to help in the choice of an appropriate xenodiagnostic agent which, if capable of sustaining fast development and vigorous multiplication of the few parasites ingested from the chronic host, would leave less room for false negative cases.

In the selection of an adequate vector species for xenodiagnosis in hosts with chronic infections by 
different T.cruzi stocks, the graphic representation of results in Fig. 3 might be useful. But it has to be kept in mind that if the product of vector parasite interaction, namely the infectivity rate, found in the vector from xenodiagnosis, is lower than that assumed for an adequate xenodiagnostic agent, it is not always this latter that is to be blamed, it might be the parasite stock that contributed only secondarily to the vector-parasite interaction. This may be the case with " $C L$ " and " $Y$ ".

Perhaps it is appropriate to mention the discovery by Morel et al. 21 that the "CL" laboratory strain is actually a mixture of at least two subpopulations, showing different parental zymodemes. Similarly the " $Y$ " strain derived from certain laboratories showed selected subpopulations in monoclonal material and sometimes laboratory mixups, according to Morel et al. 22 Therefore the poor contribution of these stocks to the vector-parasite interaction, as shown in Fig. 3, could be due to the heterogeneity of the parasite stocks.

Puzzling also is the behavior of the "Colombiana" stock, isolated from an acute human infection by Frederici et al. ${ }^{13}$ and classified as type III by Andrade et al. ${ }^{3}$ According to the authors this parasite stock does not fit the pattern of zymodeme 3 well, a common event observed among myotropic strains classified as type III. Infectivity rates produced by this stock were extremely low, varying from $12.5 \%$ to $45 \%$ in all sylvatic vector species.

By contrast, the most efficient contribution to vector-parasite interaction in the same vector species has been given by "Sao Felipe" stock, with infectivity rates varying from $82.5 \%$ to $98.3 \%$ (Tab. 1). This stock, as stated by Miles et al. ${ }^{19}$, Andrade et al. ${ }^{3}$ and others, is associated with the enzyme pattern specific for zymodeme 2 . According to the former authors, this zymodeme is entirely domestic, causing acute and chronic disease in man.

Additional data from more parasite stocks are necessary to confirm the association of the diverse infectivity rates, produced in the same invertebrate hosts by different parasite stocks, with the isoenzymic patterns revealed by these stocks, as has been claimed for diverse parameters such as: growth rate, Dworak et al. 7; biological behavior, Andrade et al. ${ }^{3}$; antigenic expressions, Chapman et al. ${ }^{6}$ and Flint et al. ${ }^{8}$; transmission cycles, Miles et al. 18,20 and other biological characteristics.

When it comes to dealing with the final recommendation for an adequate vector species for xenodiagnosis in hosts with chronic infection by different parasite stocks, it is necessary to understand that results, as seen from the data shown in the vertical columns of Fig. 3, distinguish primary and secondary candidates for xenodiagnosis, as based on the number of parasite stocks capable of eliciting a satisfactory response in the same invertebrate hosts. With regard to this diversity it is maintained that to single out which particular vector should be used in xenodiagnosis is obviously a decision best left to the individual investigator. He will know best whether the available conditions will allow the economical rearing and maintaining of large colonies of the insects.

But above all it is necessary to bear in mind that the choice of an experimental insect model for xenodiagnosis cannot be based on the comparison of two different vector species derived from two different habitats, ncither can it be adequately judged by short lasting experiments. It is also important to screen a sufficiently large number of vector species so as to justify generalization from events.

The three most efficient candidates, $P$. megis-

\begin{tabular}{|c|c|c|c|c|c|c|c|c|}
\hline & P.me & R.ne & T.br & T.so & $T . p s$ & T.ru & T.oi & T.pe \\
\hline Săo Felipe & 00 & 0 & 0 & 0 & 00 & 00 & 00 & 10 \\
\hline Gávea & 0 & 0 & 0 & 0 & 0 & 0 & 10 & 10 \\
\hline Berenice & 0 & 0 & 0 & +0 & 00 & 0 & 10 & 0 \\
\hline FL & 0 & $\times 0$ & 0 & $\times 0$ & 0 & 0 & $\times 0$ & $\times x$ \\
\hline$Y$ & 0 & $\times 0$ & $\times 0$ & $\times 0$ & $\times 0$ & 0 & 0 & $\times 0$ \\
\hline $\mathrm{CI}$. & $\times 0$ & $\times 0$ & $\times 0$ & $\times 0$ & $\times 0$ & $\times 0$ & 0 & $\times 0$ \\
\hline Colombiana & $\times 0$ & $\times 0$ & $\times 0$ & $\times 0$ & $x \times$ & $\times 0$ & $x \times$ & - \\
\hline
\end{tabular}

Fig. 3 - Representative examples for vector species' capability to respond to chronic infections with different parasite stocks, as based on an estimated minimum infectivity rate of $60 \%$, of which $50 \%$ carry parasites counts $Z 11$ in 50 fields $O$; $x$ stands for vector spedies showing lower rates than those estimated for an efficient xenodiagnostic agent; + see Figure 1; - not done. 
tus, T. rubrovaria and $T$. vitticeps (Fig. 3), singled out in this study, are the competitors in the choice of an experimental insect model. However, the winner is undoubtedly $P$.megistus, for the further reasons clearly outlined in a recent publication ${ }^{25}$ : it is available in many parts of Brazil, easy to breed under changing laboratory conditions (temperature and humidity), its developmental time is short, locomotion is slow (an attractive feature in menaging), its longevity is long, and mortality is low. The second primary candidate, T.rubrovaria, loses because its development is rather slow, thus increasing both labor and rearing costs.

T.vitticeps, the late comer to our colony, is still regarded with some reservation, because there has not been enough time to get exact information on its biological parameters such as developmental time, growth, longevity and mortality that might indicate whether it is convenient to rear and maintain this species under our laboratory conditions. Considerations of cost are the main reason for the final decision.

To give a more complete answer to the question as to the practical implication of the results obtained, it is possible to presume that, if the parasite strain type has been already identified in the endemic area under consideration, the vectorparasite interactions shown in Fig. 3, when sustained by additional data from more parasite stocks, might indicate which particular vector should be used for a satisfactory vector-parasite association, thus making xenodiagnosis most productive. Our reasoning has been based on the concept stressed by Andrade ${ }^{2}$ and Andrade et al. ${ }^{3}$ that strains from the same geographical edemic area belong to only one strain type.

PERLOWAGORA-SZUMLEWICZ, A. et al. Estudos em busca de um inseto modelo para o xenodiagnóstico em hospedeiros com doença de Chagas. 4 - O reflexo da cepa do parasito na resposta de diferentes espécies vetoras à infecçăo crónica com diferentes isolados do Trypanosoma cruzzi . Rev.Saúde públ., S. Paulo, 24: 165-77, 1990.

RESUMO: Estudos anteriores (1982, 1987) enfatizaram a superioridade das espécies vetoras silves tres às domiciliadas, como agentes do xenodiagnóstico nas infecçóes agudas e crônicas pelo isolado $Y$ do T.cruzi. Os dados atuais estabeleceram a generalidade deste fenômeno. Por exemplo, a proporçăo de positivos nas infecçöes por "Såo Felipe" variou de $82,5 \%$ a $98,3 \%$ nos vetores silvestres, caindo para $42,5 \%$ a $71,3 \%$ em especies domiciliadas. Ficou claro o envolvimento do isolado do T.cruzi na resposta do vetor a infecço crónica por T.cruzi. Por exemplo, os indices de infectividade produzidos por "Berenice", " $Y^{\prime \prime}$, "FL" e "CL" variaram de $56,3 \%$ a $83,3 \%$ em P.megistus e de $28,8 \%$ a $58,8 \%$ em $T$.sordida. Sendo a resposta das mesmas espécies vetoras às infecçóes agudas pelos mesmos isolados altamente uniformes, aproximando-se a 100\%, sugere-se que a grande carga parasitária nas infecçoes agudas oculta as diferenças interes pecificas existentes entre os isolados do T.cruzi. A análise dos dados obtidos levou a especular que resultados adicionais de mais isolados permitiriam associar os indices de infectividade, produzidos por diferentes isolados do T.cruzi, aos perfis isoenzimáticos revelados por esses.

DESCRITORES: Tripanossomose Sul-Americana, diagnóstico. Insetos vetores, parasitologia. Relaçöes hospedeiro-parasita. Triatoma, parasitologia. Panstrongylus, parasitologia. Rhodnius, parasitologia. Trypanosoma cruzi, patogenicidade.

\section{REFERENCES}

1. ALVARENGA, N. J. \& BRONFEN, E. Integração do Tripanosoma čruzi com diferentes vetores: uso para o xenodiagnóstico. Rev. Soc. bras. Med. trop., 17: 145-9, 1984.

2. ANDRADE, S. G. Caracterização de cepas do Trypanosoma cruzi isoladas no Recôncavo Baiano (Contribuição ao estudo da patologia geral da Doença de Chagas em nosso meio). Rev. Pat. trop., 3: 65121, 1974.

3. ANDRADE, V.; BRODSKIN, C.; ANDRADE, S. G. Correlation between isoenzyme patterns and biological behaviour of different strains of Tripanosoma cruzi. Trans. roy. Soc. trop. Med. Hyg., 77: 796-9, 1983.

4. BARRETO, M. P. Possible role of wild mammals and triatomines in the transmission of Trypanosoma cruzi to man. In: Intemational Symposium on New Approaches in American Trypanosomiasis $\mathrm{Re}$ - search, Belo Horizonte, MG, 1975. Proceedings. Washington, D. C., Pan American Health Organization, 1976. p. 307-16 (PAHO - Scientific Publication, 318).

5. BARRETO, A. C.; MARSDEN, P. D.; CUBA, C. C.; ALVARENOA, N. J. Estudo preliminar de Dipetalogaster maximus (Uhler, 1894) (Triatominae) na técnica do xenodiagnóstico em forma crônica da Doença de Chagas. Rev. Inst. Med. trop. S. Paulo, 20: 183-9, 1978.

6. CHAPMAN, M. D.; SNARY, D.; MILES, M. A. Quantitative differences in the expression of 72.000 molecular weight cell surface glycoprotein (GP72) in Trypanosoma cruzi zymodemes. J. Immunol., 132: 3149-53, 1984.

7. DWORAK, J. A.; HARTMAN, D. L; MILES, A. M. Trypanosoma cruzi: correlation of growth kinetics to 
zymodeme type in clones derived from various sources. J. Parasitol., 27: 472-4, 1980.

8. FLINT, J. E.; SCHECHTER, M.; CHAPMAN, M. D.; MILES, A. M. Zymodeme and species specificities of munoclonal antibodies raised against Trypanosoma cruzi. Trans. roy. Soc. trop. Med. Hyg., 78: 193-202, 1984.

9. FORATTINI, O. P.; ROCHA E SILVA, E. O.; RABELLO, E. X.; REHDER DE ANDRADE, j. C.; CORREIA RODRIGUES, W. L. C. Aspectos ecológicos da tripanossomíase americana. XIII - Potencial enzoótico doméstico em área de ocorrência de Panstrongylus megistus sob vigilância epidemiológica. Rev. Saúde públ., S. Paulo, 12: 417-24, 1978.

10. FORATTINI, O. P.; FERREIRA, O. A.; ROCHA E SILVA, E. O; RABELLO, E. X. Aspectos ecológicos da tripanossomíase americana. XIV - Persistência e potencial de domiciliação de populações triatomínicas silvestres em regiāo de intensa atividade agropecuária. Rev. Saúde públ., S. Paulo, 13: 123-46, 1979.

11. FORATTTNI, O. P.; BARATA, J. M. S.; SANTOS, J. L. F.; SILVEIRA, A. C. Hábitos alimentares, infeç̧ảo natural e distribuição de triatomíneos domiciliados na Regiāo Nordeste do Brasil. Rev. Saúde públ., S. Paulo, 15: 113-64, 1981.

12. FORATTINI, O. P.; BARATA, J. M. S.; SANTOS, J. L. F.; SILVEIRA, A. C. Hábitos alimentares, infecção natural e distribuição de triatomíneos domiciliados na Região Central do Brasil. Rev. Saúde públ., S. Paulo, 16: 171-204, 1982.

13. FREDERICI, E. E.; ABELMANN, W. B.; NEVA, F. A. Chronic and progressive myocarditis and myositis in $\mathrm{C}_{3} \mathrm{H}$ mice infected with Trypanosoma cruzi. Amer. J. trop. Med. Hyg., 13: 272-80, 1964.

14. GAMBOA, A. J. Comprobación de Rhodnius prolixus extradométicos en Venezuela. Bol. Ofic. sanit. pa. namer., 54: 18-25, 1963.

15. GARCIA, E. S.; VIEIRA, E.; GONÇALVES, A. M.; MOREL, C. M.; COLLI, M. A. W. A strain of Trypanosoma cruzi and its biochemical characterization after passage through different invertebrate hosts. Ann. trop. Med. Parasit., 80: 361-3, 1986.

16. GOMEZ-NUNEZ, J. C. Resting places, dispersal and survival of $\mathrm{CO}^{60}$ tagged adult Rhodnius prolixus. $J$. med. Ent., 6: 83-6, 1969.

17. LITTLE, J. W.; TAY, J.; BIAGI, F. A study of the susceptibility of triatomid bugs to some Mexican strains of Trypanosoma cruzi. J. med. Ent. 3: 2525. 1966.

18. MILES, M. A.; TOYE, P. J.; OSWALD, S. C.; GODFREY, D. G. The identification by isoenzyme pattems of two distinct strain-groups of Trypanosoma cruzi, circulating independently in a rural area of Brazil. Trans, roy. Soc. trop. Med. Hyg., 71: 217-25, 1977.
19. MILES, M. A.; LANHAM, S. M.; DE SOUZA, A. A.; PÓOA, M. Further enzymic characters of Trypanosoma cruzi and their evaluation for strain identification. Trans, roy. Soc, trop. Med. Hyg., 74: 221-37, 1980.

20. MILES, M. A. \& CIBULSKIS, R. E. Zymodeme characterization of Trypanosoma cruzi. Parasit. Today, 2: 94-101, 1986.

21. MOREL, C.; CHIARI, E.; PLESSMANN CAMARGO, E.; MATTHEI, D. M.; ROMANHA, A. J.; SIMPSOM, L. Strains and clones of Trypanosoma cruzi can be characterized by pattem of restriction endonuclear products of kinetoplast DNA minicircles. Proc. Nat. Acad. Sci., 77: 6810-4, 1980.

22. MOREL, C. M.; DEANE, M. P.; GONÇALVES, A. M. The complexicity of Trypanosoma cruzi populations revealed by schizodeme analysis. Parasit. Today, 2: 94-101, 1986.

23. PERLOWAGORA-SZUMLEWICZ, A. \& MULLER, C. A. Studies in search of a suitable experimental insect model for xenodiagnosis in hosts with Chagas' disease. 1- Comparative xenodiagnosis with nine triatominae species of animals with acute infections by Trypanosoma cruzi. Mem. Inst. Oswaldo Cruz, Rio de Janeiro, 77: 37-53, 1982.

24. PERLOWAGORA-SZUMLEWICZ, A. \& MULLER, C. A. Studies in search of a suitable experimental insect model for xenodiagnosis of hosts with Chagas' disease. 2- Attempts to upgrade the efficiency and reliability of xenodiagnosis in chronic Chagas' disease. Mem. Inst. Oswaldo Cruz, Rio de Janeiro, 82: 259-72, 1987.

25. PERLOWAGORA-SZUMLEWICZ, A.; MULLER, C. A.; CARVALHO MOREIRA, C. J. de Studies in search of a suitable experimental insect model for xenodiagnosis of hosts with Chagas' disease. 3. On the interaction of vector species and parasite strain in the reaction of bugs to infection by Trypanosoma cruzi. Rev. Saúde públ., S. Paulo, 22: 390-400, 1988.

26. ROCHA E SILVA, E. O.; DIAS JUNIOR, J.; GUARITA, D. F. Suspensão do rociado no combate ao Triatoma infestans na área do Estado de São Paulo, Brasil. Rev. Saúde Públ., S. Paulo. 3: 173-81, 1969.

27. RYCKMAN, R. E. Epizootiology of Tripanosoma cru$z i$, in South-western North America. V - Hostparasite specificity between Trypanosoma cruzi and Triatominae (Kineoplastida: Trypanosomidae) (Hemiptera: Triatominae). J. med. Ent., 2: 96-9, 1965.

28. SILVEIRA, A. C.; RAMOS FEITOSA, V.; BORGES, R. Distribuição de triatomíneos capturados no ambiente domiciliar, no período 1975/83, Brasil. Rev. bras. Malar., 36: 15-312, 1984.

Received for publication: 23/6/1989 Reviewed in: $5 / 12 / 1989$

Accepted for publication : 14/12/1989 